\title{
MARTÍRIO E AUTORIDADE NA TRAMA NOTICIOSA DO CASO TIM LOPES
} Márcio Castilho ${ }^{1}$

\begin{abstract}
Resumo: $O$ artigo tem o objetivo de examinar a cobertura do jornal O Globo no caso Tim Lopes. O repórter da Rede Globo foi torturado e assassinado em 2002 quando apurava denúncias de tráfico de drogas e exploração sexual de jovens num baile funk no Complexo do Alemão, Zona Norte do Rio de Janeiro. Examinaremos como o periódico construiu a história do assassinato, as estratégias narrativas e as motivações que levaram O Globo a transformar o episódio num acontecimento de grande repercussão, com características textuais de forte carga dramática e apelo ao valor emocional.
\end{abstract}

Palavras-chave: Imprensa, Narrativa e Autoridade Jornalística

Abstract: The article aims to review the coverage of $O$ Globo newspaper on the Tim Lopes case. The Globo Network reporter was tortured and murdered in 2002, when he was investigating allegations of drug trafficking and sexual exploitation of young people in a funk party at the Complexo do Alemão community, North Zone of Rio de Janeiro. We will examine how the journal has built the murder's story, the narrative strategies and the motivations that led $O$ Globo to turn the episode into an event of great impact, with textual characteristics of strong dramatic charge and appeal to the emotional value.

Key-words: Press, Narrative, and Journalistic Authority

A morte do jornalista Tim Lopes - assassinado na noite de 2 de junho de 2002, quando apurava denúncias de tráfico de drogas e exploração sexual de jovens num baile funk da Vila Cruzeiro, no Complexo do Alemão, Zona Norte do Rio de Janeiro - provocou reação imediata dos meios de comunicação do Rio de Janeiro e do país. Uma das empresas do grupo de comunicação do qual o jornalista fazia parte, $O$ Globo ocupou posição de destaque no papel de divulgador das informações para a sociedade. O jornal liderou uma campanha pela elucidação do caso, cobrando a prisão imediata dos assassinos. A pressão exercida sobre a investigação se deu através de uma narrativa com forte apelo emocional, na qual percebe-se uma vontade interdita do jornal de vingar a morte de Tim. Era mais do que um simples caso de polícia.

Desde a confirmação da morte do jornalista até a prisão de Elias Maluco, foram 100 dias de repercussão mais intensa do jornal. As matérias reportando o acontecimento ganharam a primeira página de $O$ Globo 31 vezes nesse período. A cobertura provocou o que alguns autores classificam de "suspensão do tempo". Tais eventos interrompem o fluxo da mídia,

\footnotetext{
${ }^{1}$ Doutor em Comunicação e Cultura (ECO-UFRJ), professor substituto da Universidade Federal Fluminense e jornalista da Universidade Federal do Rio de Janeiro. Email: castilhorio@ hotmail.com
} 
alteram a programação das emissoras de rádio e televisão e mobilizam a redação dos jornais para a publicação de edições extras e cadernos especiais ${ }^{2}$.

O caso Tim Lopes em $O$ Globo pode ser dividido em três fases: o anúncio da morte, em 10 de junho de 2002, marca o início da cobertura; a segunda fase, referente ao desenvolvimento da trama policial, baseia-se nas cobranças do jornal pela captura dos executores; a prisão do traficante Elias Maluco, veiculada em 20 de setembro de 2002, representa o desfecho da trama noticiosa. Apontado como principal responsável pela morte do repórter, Elias Maluco era o último bandido acusado do crime que permanecia foragido.

$\mathrm{O}$ artigo tem o objetivo de examinar como o jornal enquadrou as notícias sobre a vítima e a prisão do criminoso. Investidos de uma autoridade cultural, com poder para organizar a experiência e revelar acontecimentos que permaneceriam como eventos isolados não fosse a sua atuação, os jornalistas exploram recursos narrativos que apelam às sensações de um público amplo e diversificado. A particularização dos detalhes, as dualidades, o apelo ao valor emocional e a unidade dramática estão presentes no noticiário. Apresentam características textuais semelhantes ao cenário do melodrama, com a montagem do enredo, a oposição herói versus vilão, o crescimento/ declínio da ação e a estrutura narrativa com começo, meio e fim.

Para além da análise da forma como essas estratégias aparecem no noticiário, importa verificar os motivos que levaram o periódico a produzir uma narrativa que não apenas informa sobre o crime, mas transforma o assassinato em "martírio" do profissional da Rede Globo. Estava em jogo fortalecer o vínculo do jornal com os leitores? A cobertura também não teria contribuído para reforçar a autoridade dos jornalistas como produtores de sentido, reafirmando valores morais através da punição daqueles que se afastam dos princípios dominantes na sociedade?

\section{O "martírio"}

O jornalista Tim Lopes fazia uma reportagem na Vila Cruzeiro, uma das favelas do Complexo do Alemão, na Zona Norte do Rio de Janeiro, para ser exibida no programa

\footnotetext{
${ }^{2}$ No caso brasileiro, são exemplos dessas cerimônias ininterruptas da televisão as mortes do presidente Tancredo Neves, do piloto de Fórmula 1 Ayrton Senna e dos integrantes do grupo Mamonas Assassinas. Sobre o tema cf. Barbosa (2004). A morte imaginada. CD Rom do XIII Encontro Anual da COMPÓS, 2004. São Bernardo; O dia em que o Brasil parou. A morte de Tancredo Neves como cerimônia midiática. Texto apresentado no VII Colóquio Brasil-França de Ciências da Comunicação. Porto Alegre, 2004. Os gestos do público e a construção do modelo cerimônia da televisão brasileira. In Comunicação e Sociedade, São Paulo. V. 41, pp. 73-93, 2004.
} 
Fantástico, da Rede Globo de Televisão. Investigava denúncias de tráfico de drogas e aliciamento de menores para a prática de sexo num baile funk quando foi capturado por bandidos, provavelmente, na noite de 2 de junho de 2002. As notícias sobre a confirmação da execução do jornalista, que marcam o início da trama narrativa, aparecem no noticiário de $O$ Globo em 10 de junho de 2002. O jornal estampou na manchete: "Tráfico julgou, torturou e executou Tim Lopes".

Da Vila Cruzeiro, a vítima foi levada, segundo a reconstituição feita por jornalistas, para a vizinha Favela da Grota, onde estavam Elias "Maluco" e o traficante Renato Souza de Paula, o "Ratinho". Os narradores presumem a realidade, pois não estavam presentes na cena do crime. Até chegar ao local identificado como "microondas", no alto do morro, o repórter teria sido espancado e baleado nos pés para evitar uma tentativa de fuga. Com as mãos amarradas para trás, os criminosos o empurraram para dentro do porta-malas de um Fiat Palio.

No alto do morro, Elias Maluco, Boizinho, André Capeta e Ratinho fizeram um julgamento para decidir a execução do jornalista. A decisão foi rápida e, por volta das 24 horas, Tim foi assassinado. A polícia investiga a informação de que o corpo do jornalista esteja enterrado num cemitério clandestino, naquela favela, ao lado do local chamado microondas, onde traficantes matam e queimam seus rivais ("Repórter é executado pelo tráfico". O Globo, 10/06/2002, pág. 12)

O jornalista foi torturado até a morte sob o comando de Elias Maluco, segundo as investigações policiais reproduzidas no noticiário. Os repórteres que cobriram o caso acentuam o caráter dramático de uma cena não testemunhada por eles. O sentido de onipresença dos profissionais se destaca na cobertura. A narrativa apela para imagens contundentes, expressivas: a decisão rápida, os pés sangrando, o julgamento sumário, os golpes da espada do tipo samurai.

Com as mãos amarradas, os pés sangrando em conseqüência de tiros, o repórter Tim Lopes, de 51 anos, foi levado para o alto da favela da Grota, no Complexo do Alemão, no final da noite do domingo passado. Os traficantes, comandados por Elias Pereira da Silva, o Elias Maluco, improvisaram um julgamento sumário e decretaram a execução do jornalista, que já havia sido espancado pouco antes. O repórter foi morto a golpes de uma espada do tipo samurai e seu corpo foi queimado ("Repórter é executado pelo tráfico". $O$ Globo, 10/06/2002, pág. 12)

A localização de fragmentos da microcâmera usada por Tim e de restos mortais carbonizados de um corpo que poderia ser o do jornalista foi noticiada em 12 de junho de 2002. Policiais fizeram a descoberta num cemitério clandestino no alto da Favela da Grota. 
Objetos pessoais, como um cordão de ouro, uma camisa, uma pochete e um chinelo, que pertenciam supostamente ao repórter também foram encontrados pelos investigadores. A prática de queimar o corpo, num tonel formado por pneus encharcados de gasolina, era usada por bandidos para dificultar a identificação das vítimas. Partes da microcâmera resistiram ao calor. O equipamento tinha a plaqueta de patrimônio da TV Globo.

\begin{abstract}
Além de torturar e matar suas vítimas, os traficantes dos morros e favelas cariocas estão utilizando, cada vez mais, um outro recurso, igualmente cruel, para dificultar a identificação das pessoas por eles assassinadas: a destruição, com fogo, dos corpos. O procedimento, chamado de microondas, consiste na utilização de pneus e gasolina para queimar os corpos das vítimas ("Microondas, a técnica macabra". O Globo, 15/06/2002, pág. 13)
\end{abstract}

Observamos que os detalhes do assassinato, acentuando a brutalidade dos criminosos no alto da Favela da Grota, e a ênfase na descrição do "microondas" como meio de extermínio reaparecem sempre que os repórteres precisam relembrar o caso ao longo dos 100 dias de cobertura em $O$ Globo. O jornal não apenas informa sobre o crime, mas remonta os últimos momentos da vítima na perspectiva do martírio de um profissional que estava na favela para livrar seus moradores das amarras do tráfico. As narrativas se apóiam na idéia de sacrifício de um homem que, após ser torturado, esquartejado e queimado, ofereceu a vida em troca de um novo momento para a segurança pública do país.

O apelo a valores que transcendem o espaço restrito da ocorrência pode ser ilustrado em outros momentos da cobertura. Tomamos como exemplo a matéria reportando o sepultamento dos restos mortais do repórter no Cemitério Jardim da Saudade, em Sulacap, no Rio de Janeiro. Depois de ter sido noticiado que o corpo de Tim Lopes havia sido identificado a partir da análise de um fragmento de costela com restos de músculo, feita pela Universidade Federal do Rio de Janeiro (UFRJ), o frei David Raimundo declarou: "Assim como de uma costela (a de Adão), Deus criou a humanidade, esperamos que da costela de Tim surja um momento novo para a segurança pública de todo o país" ("Parentes e amigos dão adeus a Tim Lopes”. O Globo, 08/07/2002, pág. 14)

O jornalista, ao selecionar esse tipo de relato, vai buscar elementos narrativos em fatos anteriores ao próprio acontecimento. Por isso destaca a associação entre a costela de Adão e os restos mortais de Tim Lopes como marcos fundadores da criação do homem e da reformulação da segurança pública do país, respectivamente. As estratégias narrativas resgatam o passado para conformar as notícias do presente produzindo uma significação futura. 
Com a descoberta dos restos mortais, o jornal assume a tarefa de construir a biografia oficial do repórter. É a partir deste acontecimento que a história de vida e o seu trabalho no jornalismo policial são rememorados para a construção de um personagem até então desconhecido do público. O repórter passa a existir verdadeiramente depois da sua morte.

O jornal destaca a juventude de Tim e o reconhecimento por parte da comunidade jornalística por ele ter se transformado em repórter investigativo. Tim construiu sua trajetória como aquele que - para ser jornalista - deveria vivenciar a vida de outros de modo a desvendar para o leitor um mundo desconhecido. Como repórter, ele tinha por delegação a tarefa de torná-lo conhecido. Para isso, transmutava-se em outro personagem, ocultando sua própria identidade. Esse aspecto é muitas vezes valorizado no jornalismo, pois assim, de certa forma, a profissão se transforma em algo simbolicamente maior: não é apenas relato dos fatos, mas vivência cotidiana das transgressões, descobertas, desvelamento. Mais importante do que informar é descobrir.

O talento especial para o jornalismo investigativo estava mesmo no sangue de Tim Lopes. Em 1979, em início de carreira, o jovem repórter, com então 26 anos, ganhou o reconhecimento e elogios dos editores do Jornal "Repórter" (uma publicação de esquerda editada no Governo Figueiredo) com uma reportagem sobre a vida sofrida dos operários que construíam o sistema metrô. Tim havia se passado por servente para conseguir trabalhar, durante dois dias, no canteiro de obras instalado na Rua Ana Néri, no pé do Morro da Mangueira ("Um repórter peão para toda obra". O Globo, 12/06/2002, pág. 16)

Observamos que $O$ Globo, em suas primeiras reportagens sobre o assassinato, trata de apresentar a vítima ao público, com a elaboração de um personagem que "tinha o olhar de pessoas comuns", carregando no sangue "o talento especial para o jornalismo investigativo". Os títulos também parecem guiar o olhar dos leitores para a imagem que eles devem fixar na lembrança sobre Tim Lopes: "Um repórter peão para toda obra" ou, como informa a matéria "Um repórter que se chamava Arcanjo" ( $O$ Globo, 10/06/02), aquele "que já no nome era um anjo de ordem superior". Seu desaparecimento parece ter dado sentido definitivo a sua biografia.

\section{Narrativa: pressupostos da abordagem}

A cobertura do caso Tim Lopes fornece farto material para discutirmos a relação que se estabelece entre as notícias que devem apresentar uma realidade próxima ao leitor e as 
exigências da objetividade. Compartilhamos a idéia de que o discurso do jornal não é considerado legítimo apenas por manter certo distanciamento, mas por estimular uma constante identificação com o público ao qual se dirige. Para isso, os produtores de notícias se valem da narrativa, ainda que sob uma roupagem de neutralidade e isenção.

Ricoeur (1997) propõe uma interseção entre o mundo do texto e o mundo do leitor, pois somente pela intervenção do leitor é que as mensagens adquirem significância completa. Nesse sentido, o receptor deve ser visto como um sujeito ativo do processo comunicacional. $\mathrm{O}$ que existe entre as partes é uma relação de troca, nunca de submissão do leitor perante a obra, visto que o texto está aberto a um número variado de interpretações.

Considerado à parte da leitura, o estatuto ontológico do mundo do texto permanece em suspenso: "sem leitor que o acompanhe, não há ato configurante em ação no texto; e sem leitor que se aproprie dele, não há mundo desdobrado diante do texto" (Ricoeur,1997: 283). Percorre-se então um caminho que tem seu ponto de partida no autor e atravessa a obra até chegar ao leitor. A inscrição da estratégia de persuasão do autor no espaço da recepção pode variar uma vez que a obra apresenta lacunas ou "lugares de indeterminação". Para Ricoeur, o que faz da leitura uma experiência viva é o grau de interação entre o texto e o leitor.

O momento em que a literatura atinge sua eficiência mais alta talvez seja aquele em que ela põe o leitor na situação de receber uma solução para a qual ele tem de encontrar as questões apropriadas, aquelas que constituem o problema estético e moral colocado pela obra (Ricoeur,1997: 295).

Todorov (2004) também entende que a narrativa sempre implica numa relação de interação com o leitor. Nesse sentido, há uma "função de leitor" que está inscrita no próprio texto. Ao fazer diferentes interpretações da leitura e se identificar com o acontecimento, o leitor tende a sair da posição de receptor da mensagem para se integrar ao mundo narrado.

Vistas algumas considerações sobre a dialética entre o mundo do texto e o mundo do leitor, gostaríamos de explorar a questão da narrativa como recurso jornalístico, procurando entender até que ponto os meios de comunicação adquirem poder em função de sua capacidade de se estender sobre o imaginário do leitor. O próprio Ricoeur observou que as estórias devem estar interligadas no tecido narrativo, ou seja, serem reconhecidas como estórias, se os leitores quiserem compreendê-las bem.

Elizabeth Bird e Robert Dardenne (1993) afirmam que relatar notícias significa, de fato, construir estórias. Os autores procuram fazer uma análise das qualidades narrativas das notícias e, para isso, defendem que as estórias noticiosas devem ser observadas como um todo 
e não apenas através da dicotomia importante/ interessante ou da divisão hard para matérias informativas e factuais e soft para notícias leves e divertidas. Segundo eles, pouco há que sugira que o público perceba o mundo como se este estivesse tão claramente dividido. Para os autores, considerar as notícias enquanto narrativas "introduz outra dimensão às notícias, dimensão essa na qual as estórias de notícias transcendem as suas funções tradicionais de informar e explicar" (Bird e Dardenne, 1993: 265).

Por não se limitar apenas em informar ou relatar fatos, mas, sobretudo, construir linhas de estória de acordo com o uso do suspense e do conflito, o jornalista tende a controlar a capacidade de reação do público. Afinal, cabe ao produtor de notícias, através de um poder que lhe é conferido, colocar pessoas e acontecimentos em categorias de herói e vilão, o bem e o mal. É neste sentido que os repórteres reforçam sua autoridade atuando como os antigos contadores de histórias. O público tem tendência a acreditar nesses especialistas em categorizar personagens e enquadrar ocorrências. Por isso, são considerados os profissionais com mais autoridade em produzir informação "verdadeira".

Investidos de uma autoridade cultural, com poder para organizar a experiência e produzir sentidos, os repórteres exploram recursos narrativos que fortalecem o vínculo do jornal com os leitores. Para isso, apelam às sensações do público, através da particularização dos detalhes, as dualidades, o apelo ao valor emocional e a unidade dramática. No caso Tim Lopes, observamos que os jornalistas construíram a história do assassinato exatamente com base em características textuais que apontam para o dado ficcional e a oposição entre o herói e o vilão, o bem e o mal. Interessa-nos abordar os pormenores da cobertura do caso Tim Lopes, sobretudo o jogo de palavras que aproxima o mundo narrado da realidade do público. Ao construir linhas de ação dramática, reforçando, por exemplo, a brutalidade de Elias Maluco, os repórteres reafirmam valores dominantes na sociedade, aplicando punição moral aos acusados.

\section{O desfecho da trama}

Último foragido de uma lista de nove acusados da morte do repórter, o traficante Elias Pereira da Silva, o Elias Maluco, foi preso no dia 19 de setembro de 2002. O episódio marcaria o capítulo final dos 100 dias de cobertura. O Globo publica, no dia seguinte, amplo noticiário sobre a captura do bandido. Descalço e sem camisa, ele não ofereceu, segundo a notícia, resistência ao cerco de 250 policiais. Fez apenas um pedido antes de ser retirado do esconderijo no Beco do Brizola, uma das vielas da Favela da Grota no Complexo do Alemão: 
"Perdi, chefe. Mas não esculacha". O traficante usou uma expressão típica das camadas populares, conhecida no meio policial, para não ser morto. A declaração reproduzida na manchete transporta para o relato um forte elemento de identificação com o público.

Mais do que um bandido, a crueldade de Elias Maluco era o contraponto da generosidade da vítima. Desde o anúncio do assassinato de Tim Lopes, o jornal reforçou o caráter monstruoso de Elias Maluco, identificado com bandido de "nenhum cérebro" e de "pura violência":

Um traficante que usa a violência extrema para impor seu comando e subjugar os moradores das favelas sob seu domínio. Elias Pereira da Silva é, segundo a inspetora Marina Maggessi, da Delegacia de Repressão a Entorpecentes (DRE), um bandido sem cérebro, pois não consegue administrar os negócios da sua quadrilha. (...)Tem um grande arsenal e um exército violento, mas só consegue vender drogas a outros bandidos nas favelas que domina. (...) - Elias é pura violência, por isso passou a ser conhecido como Elias Maluco - afirmou Marina Maggessi ("Recompensa oferecida pode valer R $\$ 50$ mil”. O Globo, 10/06/2002, pág. 13)

A matéria, publicada ainda sob o impacto da confirmação da morte do jornalista, prossegue enumerando a seqüência de crimes do bandido, enfatizando a crueldade aplicada contra suas vítimas. Segundo o relato dos jornalistas, era prática comum o traficante torturar inimigos e incinerar os corpos, além de "obrigar parentes dos condenados pelo 'tribunal do tráfico' a executar a sentença'.

Segundo o delegado Reginaldo Guilherme, da $38^{\mathrm{a}}$ DP (Brás de Pina), Elias Maluco comandou a execução de 60 pessoas nos últimos 12 meses. Todas as mortes foram antecedidas por sessões de torturas. Muitas das vítimas tiveram os corpos incinerados em fornos improvisados pelos traficantes nas partes mais altas e isoladas das favelas. (...) Como responsável pelas execuções das sentenças determinadas pelos chefes do bando, sentia prazer em ser cruel. Por várias vezes, obrigou parentes dos condenados pelo "tribunal do tráfico" a executar a sentença. Pelo menos em quatro casos as vítimas foram assassinadas por seus próprios irmãos ("Recompensa oferecida pode valer R\$ 50 mil”. O Globo, 10/06/2002, pág. 13).

Para estabelecer a oposição entre os personagens centrais da trama, $O$ Globo insere uma pequena chamada no fim da matéria, que remete ao título da página seguinte: "O repórter que se chamava Arcanjo, na página 14". Assim o noticiário põe em lados distintos o herói e o vilão. Enquanto Tim Lopes aparece em manchetes como "Repórter ajudava família de presos assassinados" e "Um repórter peão para toda obra", Elias Maluco era o "protagonista de crimes cruéis", como sugere o título de $O$ Globo, de 12 de junho de 2002. Nesta matéria, o 
jornal também constrói o perfil do antagonista a partir da descrição da extensa ficha de crimes do traficante, "alguns de repercussão internacional".

A biografia dos criminosos foi sendo construída a cada nova prisão ou operação policial, principalmente através da particularização dos detalhes sobre a natureza monstruosa dos traficantes. Por exemplo, na matéria "Ratinho confessa a policiais ter matado Tim Lopes", de 31 de agosto, o jornal enfatiza uma suposta declaração dada pelo bandido aos policiais: "Acendi um cigarro nos ossos em brasa dele com muito prazer". A reportagem oferece mais do que um relato dado como objetivo e factual.

Nas notícias policiais, o apelo às dualidades constitui uma das estratégias que facilitam a identificação da matéria com o leitor. A narrativa mesclou realismo e romance, recorrendo, sobretudo, ao contraste das imagens, como na reportagem de 20 de setembro de 2002. A sequiência textual constrói a cena dual, que busca seduzir o público: a "tranquuilidade no morro" em contraposição ao "barulho das comemorações" no asfalto.

O silêncio da aparente tranqüilidade no morro onde Elias Maluco foi capturado contrastou ontem com o barulho das comemorações e dos comentários no asfalto por toda a cidade ("Silêncio no morro, comemoração no asfalto". O Globo, 20/09/2002, pág.16).

Todos podiam acompanhar o enredo, familiarizar-se com a vítima, conhecer os hábitos do seu algoz num exercício de identificação ou repulsa, auto-reconhecimento e pertencimento entre as partes. Importa transportar o leitor para a cena do acontecimento:

No trajeto feito pelo comboio da polícia, aplausos puderam ser ouvidos na altura de Bonsucesso, por exemplo. No fórum e na Chefia de Polícia Civil não faltaram curiosos, que não se contentavam em assistir apenas e caprichavam nos gritos de repúdio ao traficante ("Silêncio no morro, comemoração no asfalto". O Globo, 20/09/2002, pág.16)

A mesma reportagem informava que a captura do bandido era o principal assunto nos bares e nas rodas de conversa por toda a cidade. As notícias valorizam a importância da captura do bandido, assunto que teria mobilizado naquele dia a população de toda a cidade.

No caminho, guardas de trânsito também apitavam e faziam sinal de vitória para as equipes de polícia que passavam com o traficante preso. Até na Zona Sul, após as primeiras notícias da prisão de Elias Maluco, houve comentários nos bares e as pessoas se aglomeravam em volta dos aparelhos de televisão 
para conseguir mais informações sobre o grande assunto do dia ("Silêncio no morro, comemoração no asfalto”. O Globo, 20/09/2002, pág.16)

Apresentando o acontecimento como um fato histórico, demarcado pela mobilização popular que desperta, a imprensa faz com que o leitor se comprometa a acompanhar o desenrolar dos fatos. Cria-se uma espécie de cidade imaginária, transportando elementos narrativos de conhecimento do público para as notícias de crime. Para Barbosa (2004), a estratégia que enfoca valores individuais como coletivos tem a função de legitimar produtos simbólicos. A publicação de temas do âmbito do privado, como se fossem de toda a sociedade, e o estímulo à opinião pública são instrumentos de que os periódicos se valem, segundo a autora, para capturar o poder.

Diante do crime organizado, surgem os "meninos de ouro" numa referência ao grupo de 25 policiais da Divisão de Capturas Oeste da Polinter (DC-Oeste). "Afinal, eles botaram atrás das grades o inimigo público número 1 do Rio".

O grupo responsável pela prisão de Elias Maluco faz parte da nova cara que a Polícia Civil quer implantar: policiais com curso superior e disposição para enfrentar a criminalidade ("Os meninos de ouro". $O$ Globo, 21/09/2002, pág. 16)

Matérias como "Os meninos de ouro" apontam para a glorificação de um grupo de policiais com "curso superior e disposição para enfrentar a criminalidade". O novo perfil da polícia surge, na reportagem, como o contraponto dos investigadores corruptos, dos grupos de extermínio formado por "bandidos de farda" e dos policiais militares acusados de vender proteção para Elias Maluco. Devemos entender as notícias dentro de processos de longa duração, pois nelas residem pormenores simbólicos. Como informa Rondelli (2003), a imprensa constrói representações sociais sobre o crime, a violência e os agentes envolvidos em suas práticas e em sua coibição. Os atos de violência revelam uma dimensão simbólica que transcende os limites da sua ocorrência. Um texto jornalístico passa a comunicar sobre um além-episódio.

Assim, quando a imprensa resgata a expressão "meninos de ouro" ela se dirige na verdade contra os policiais "truculentos" do passado. Os jovens policiais são a resposta dos órgãos de segurança ao sentimento de desordem e insegurança. A mídia quer registrar também o acontecimento como um momento fundador contra a violência na cidade. 
A Polícia Civil do Rio inaugurou uma nova fase com a prisão de Elias Maluco. A truculência de outros tempos deu lugar à técnica e à estratégia arquitetadas nos mínimos detalhes ("Um trabalho minucioso da polícia". $O$ Globo, 20/09/2002, pág. 17).

Novamente percebemos a ênfase em valores duais, como a substituição dos métodos de investigação policial. O que era truculência passa a ser um trabalho baseado em técnicas e estratégias minuciosas de combate ao crime organizado. Com a captura dos principais envolvidos no assassinato de Tim Lopes, a imprensa acaba por reforçar o discurso policial. Na ocasião da prisão de Ratinho, o comandante-geral da PM, coronel Francisco Braz, já havia declarado que a bem-sucedida operação era a resposta dos órgãos de segurança às denúncias de corrupção envolvendo os policiais. Uma prisão "técnica e profissional", sem que nenhum tiro fosse disparado. Com a forte pressão exercida pelo campo jornalístico, atribuições rotineiras da polícia, como a de prender criminosos, ganham outro significado:

- Ainda não caiu a ficha - disse o inspetor André Coppolla, de 30 anos, que recebeu a denúncia anônima sobre a localização do traficante Elias Maluco e o avistou no andar superior de uma casa na Favela da Grota, em Ramos. - É engraçado como todos na rua estão me cumprimentando (...) ("Dia de aplausos para a polícia”. O Globo, 21/09/2002, pág. 16)

Não foram apenas o Governo do Estado, através da Secretaria de Segurança Pública, e os jovens policiais envolvidos na prisão de Elias Maluco que capitalizaram o êxito das operações no Complexo do Alemão. A cobertura procurou mostrar a imprensa como coautora da captura do traficante. Exalta-se o papel da polícia, que era cobrada diariamente pela comunidade jornalística, mas também se legitima a imprensa como instrumento confiável para a elucidação do crime.

As notícias exercem uma tensão narrativa e mantêm os leitores sob controle, criando um clima de suspense: "Morre mais um matador de Tim" ( $O$ Globo, 14/08/02); "Ratinho é preso e só falta Elias Maluco" (O Globo, 27/08/02); "Secretário promete prender Elias em 30 dias" ( $O$ Globo, 28/08/02). Ao final da matéria "Ratinho é preso e só falta Elias Maluco", o periódico lança a seguinte pergunta para ser debatida na Internet, através do www.oglobo.com.br: “A polícia conseguirá prender Elias Maluco?”.

Há que se destacar, portanto, o poder de o jornal também instaurar presentes. Apoiado na declaração do secretário de Segurança do Rio, Roberto Aguiar, que prometera prender o 
traficante Elias Maluco em 30 dias, o jornal estabelece uma nova temporalidade. Abre-se uma contagem regressiva para a prisão de Elias Maluco.

As matérias sobre as investigações e o cerco policial a Elias Maluco se sucedem como se o jornal estivesse preparando o terreno para o grande desfecho: "Contagem regressiva - Polícia tem oito dias para cumprir promessa feita em agosto: prender Elias Maluco em um mês" ( $O$ Globo, 18/09/02); "Polícia deixa Elias Maluco sem comida" ( $O$ Globo, 19/09/02); "Perdi Chefe. Mas não esculacha - Elias Maluco é preso 109 dias após a morte de Tim" (O Globo, 20/09/02). A dimensão temporal tem forte presença na narrativa.

A captura de Elias aconteceu 48 horas após o início da Operação Sufoco da Polícia Civil, que reuniu 250 policiais por turno, e uma semana antes do prazo dado pelo secretário de Segurança Pública, Roberto Aguiar para a prisão do traficante ("Elias Maluco perdeu". O Globo, 20/09/02, pág. 14)

Através dessa estratégia narrativa, as notícias criam o suspense até reservar uma mensagem de otimismo e esperança no final da história: a captura do traficante Elias Maluco, último bandido foragido. Assim, vão dando sentido ao mundo e oferecendo uma sensação de harmonia e tranqüilidade frente aos fenômenos que fogem às regras normativas da sociedade. Ao final, o jornal destaca na cobertura o sentimento de esperança que envolve a sociedade. A matéria "Linho, traficante da Maré, é o próximo alvo" ( $O$ Globo, 20/09/02) mostra o empenho das autoridades policiais, embaladas pelo êxito da Operação Sufoco, em prender Paulo César Silva dos Santos, o Linho, principal chefe do Terceiro Comando. Depois de Maluco, o traficante passou a ser o mais procurado pela polícia carioca.

Bird e Dardenne (1993) observam que o enquadramento dramático das matérias, resgatando antigas formas de contar estórias, reforça a idéia da notícia como "narrativa mitológica".

Muita da qualidade mítica das notícias deriva de uma tal 'ressonância' - a sensação de termos escrito ou lido as mesmas "estórias' repetidas vezes" (1993: 268). Os acontecimentos são codificados em estruturas já conhecidas do público. Essa estratégia faz com que as notícias transmitam, segundo os autores, uma sensação de drama infinitamente repetido, cujos temas são familiares e bem compreendidos. "As notícias enquanto abordagem narrativa não negam que as notícias informam; claro que os leitores aprendem com as notícias. No entanto, muito do que aprendem pode ter pouco a ver com os fatos, nomes e números que os jornalistas tentam apresentar com tanta exatidão (BIRD e DARDENNE, 1993: 265). 
A narrativa como procedimento jornalístico obedece a sistemas simbólicos e processos de longa duração.

Estes pormenores - significantes e insignificantes - contribuem todos para o bem mais amplo sistema simbólico que as notícias constituem. Os fatos, nomes e detalhes modificam-se quase diariamente, mas a estrutura na qual se enquadram - o sistema simbólico - é mais duradoura (BIRD E DARDENNE, 1993: 265).

A cobertura sobre o caso Tim Lopes pelo jornal O Globo tem particularidades que transformam o crime num detalhe secundário. A narrativa obedece assim a um esquema percebido em outros dramas noticiosos. Trocam-se números, datas e nomes. Permanecem os códigos simbólicos que são reconhecidos pelo público. Nessa lógica narrativa, o leitor, por mais afastado que esteja do objeto noticiado, acaba se inserindo na tragédia alheia.

\section{Conclusão}

Ao percorrer algumas fases da cobertura do caso Tim Lopes em $O$ Globo, como o anúncio do assassinato e a prisão de Elias Maluco, não foi nosso propósito dirigir críticas sobre a conduta do repórter em sua última apuração no Complexo do Alemão. A despeito das considerações sobre os limites éticos da atuação dos chamados jornalistas investigativos, buscamos verificar a forma como as estratégias narrativas apareceram no noticiário e os motivos que levaram os jornalistas a adotar uma linguagem que, muitas vezes, se aproxima do dado ficcional.

O jornal assumiu a tarefa de construir a biografia de Tim Lopes na perspectiva do "grande morto", rememorando a história de vida e o seu trabalho no jornalismo policial. Neste processo de reatualização do passado, valorizou as virtudes da vítima e o seu legado para o futuro. Acreditamos que a narrativa não visava apenas transformar o repórter em mártir, mas reforçar a atuação dos jornalistas em favor do "bem coletivo". É interessante observar que o sentido de coesão do grupo surge a partir do incidente envolvendo um repórter assassinado.

Investidos de uma autoridade cultural, os repórteres exploram recursos narrativos que apelam às sensações do público, através da particularização dos detalhes e da apresentação de uma realidade próxima ao universo do leitor. No caso Tim Lopes, o caráter dramático da narrativa foi reforçado pelo fato de o episódio no Complexo do Alemão ter produzido junto aos produtores de notícias um sentimento de vingança pela morte de um dos seus pares.

O Globo construiu a história do assassinato utilizando muitas vezes elementos trazidos da ficção, que apontam para a oposição entre o herói e o vilão, a bondade da vítima e a 
brutalidade do crime, a inteligência dos jovens policiais e a covardia dos traficantes, a impunidade e a esperança. Assim como ocorreu na construção da biografia de Tim Lopes, o jornal também elaborou um perfil psicológico de Elias Maluco, reservando para o bandido o papel de antagonista da trama narrativa. Seus atos de violência eram o contraponto ao legado deixado por Tim Lopes. A captura do bandido, no final, representou o triunfo do bem contra o mal.

Todo este conjunto narrativo ajuda a fornecer pistas para explicar o significado da morte do repórter. Esses pormenores conferiram força ao discurso do jornal, que procurou, através da narrativa, se legitimar como autoridade interpretativa no campo social. O martírio, em outras palavras, foi formador de autoridade. 


\section{Referências bibliográficas:}

BARBOSA, Marialva. "A morte imaginada". Texto apresentado para o GT Comunicação e Sociabilidade do XIII Encontro Anual da COMPÓS, 2004. São Bernardo do Campo: UMESP.

BENJAMIN, Walter. “O narrador”. In Os pensadores. São Paulo: Abril, 1983.

BERGER, Peter L. \& LUCKMANN, Thomas. A construção social da realidade: tratado de sociologia do conhecimento. Petrópolis, Vozes, 1985.

BIRD, S. Elizabeth e DARDENNE, Robert W. "Mito, registro e 'estórias': explorando as qualidades narrativas das notícias". In TRAQUINA, Nélson (org.) Jornalismo: questões, teorias e estorias. Lisboa: Vega, 1993, pp. 263-277.

BOURDIEU, Pierre. "A ilusão do biográfico". In: FERREIRA, Marieta de M. e AMADO, Janaina (org). Usos e abusos da história oral. $2^{a}$ edição, Rio de Janeiro: FGV, 1998.

DARNTON, Robert. "Jornalismo: toda notícia que couber, a gente publica". In: O beijo de Lamourette. Companhia das Letras, 1990.

JEUDY, Henri Pierre. "Pesquisador dos processos midiáticos". In Mídia e violência urbana. Rio de Janeiro: Faperj, 1994.

MOUILLAUD, Maurice. "As grandes mortes na mídia”. In PORTO, Sérgio Dayrell (org.). $O$ jornal. Da forma ao sentido. Brasília: Ed. Universidade de Brasília, 2002.

RICOEUR, Paul. Tempo e narrativa, tomo 3. Campinas, SP: Papirus, 1997.

RONDELLI, Elizabeth e HERSCHMANN, Micael. "Os media e a construção do biográfico A morte em cena". In: HERSCHMANN, Micael e PEREIRA, Carlos Alberto Messeder (org.). Mídia, memória e celebridades - Estratégias narrativas em contextos de alta visibilidade. Rio de Janeiro: E-papers, 2003.

SCHUDSON, Michael. The politics of narrative form: the emergence of the news conventions in print and television. Dedalus: Journal of the American Academy of Arts and Sciences, 1982, pp. 97-112. Trad. Para o português de MTGF de Albuquerque e FFLA de Albuquerque.

TODOROV, Tzvetan. As estruturas narrativas. São Paulo: Perspectiva, 2004.

VOVELLE, Michel. "Sobre a morte". In Ideologia e mentalidades. São Paulo: Brasiliense, 1987. 